\title{
Assessment of Agriculture Productivity Performance in the Region of Tamilnadu Using Composite Agriculture Productivity Index
}

\author{
R. Lakshmi Priya ${ }^{1}$, C. Arul Kumar ${ }^{2}$ and G. Manimannan ${ }^{3}$ \\ ${ }^{1}$ Assistant Professor, Dr. Ambedkar Govt. Arts College, Chennai, Tamilnadu, INDIA. \\ ${ }^{2}$ Assistant Professor, Vivekanandha College of Arts and Sciences for Women, Tiruchengode, Tamilnadu, INDIA. \\ ${ }^{3}$ Assistant Professor, TMG College of Arts and Science, Chennai, Tamilnadu, INDIA.
}

*Corresponding Author: G. Manimannan, Assistant Professor, Department of Mathematics, TMG College of Arts and Science, Chennai

\begin{abstract}
Agriculture is the life line of the Indian economy and vital activity of a human being. About $65 \%$ of Indian population depends directly on agriculture and it accounts for around 15\% of GDP. Over the past decade the agriculture production in districts of Tamil Nadu had faced many challenges. However, agriculture productivity differs from region to region, which needs a detailed investigation. The main objective of this paper is to assess the agriculture productivity performance of Tamilnadu. The data was collected from secondary sources from Department of Economics and Statistics during the period of 2002-03 to 2011-12. Bhatia's Method was applied to calculate the Composite Agriculture Productivity Index. The districts were classified and labeled as Low Productivity Districts (LPD), Moderate Productivity Districts (MPD) and High Productivity Districts (HPD) based on the index values.
\end{abstract}

Keywords: Agriculture Productivity, Composite Agriculture Productivity Index, Bhatia's Method and Moving Average Method.

\section{INTRODUCTION}

Agriculture is the backbone of our Indian economy and vital activity of a human being. Agriculture and its allied activities contributes nearly $15 \%$ of nations Gross Domestic Product (GDP) and over two third of Indian population significantly depending on agriculture for their livelihood. This sector not only provides food security for the population also supplies mass of goods and raw materials required by the non-agricultural sectors. In short agriculture plays an important role in the process of development of a country.

Tamilnadu is one of the most urbanized and industrialized states in India. Agriculture continues to be the most predominant sector of Tamilnadu economy. 60 percent of the total population is directly engaged in agriculture. The annual average rainfall of Tamil Nadu is only $930 \mathrm{~mm}$ as against the national average of $1200 \mathrm{~mm}$. The total geographical area of Tamilnadu is 130 lakh hectares, which is 4 percent of the nation's geographical area, around 48.92 lakh hectares is the net cultivated land area.

Agricultural development of a country or region is depending on the production of crops. Agricultural productivity is becoming increasingly important issue as the population continues to grow. Several efforts has been taken to increase the production and productivity level at different points of time. Agriculture productivity measures the area that are performing less or higher compared with other regions nearby. The concept of agriculture productivity has been extremely used to explain the spatial organization and pattern of agriculture. Spatial analysis of agriculture productivity is very important because it can highlight the structure and pattern of production. (Dharmasiri, 2009) Agriculture productivity is defined by several researchers with their views and discipline. Agriculture productivity may be defined as the ratio of index of agriculture output to index of total input used in farm production' (Shafi, 1984) In geography agriculture productivity is defined as "output per unit of input" or "output per unit of land area". "Yield per unit" should be considered to indicate agriculture productivity (Singh and Dhilion, 2000).

In the field of agriculture productivity, various scholars have used different techniques to measure the agriculture productivity and spatial patterns at national and International level. Stamp (1958) applied 
Kendall's ranking coefficient technique on an international level in order to determine agricultural efficiency of a number of countries as well as some major crops. Shafi (1960) applied the technique of ranking coefficient of Kendall for measuring the agricultural efficiency in the state of Uttar Pradesh, taking eight crops grown in forty eight districts in the state. Rahman (2003) attempted to examine variations in crop productivity in North Bihar Plain considering 17 major crops grown in the districts of the region during the period of 1995-2000. Kalaivani et al. (2010) used Compound Growth Rate to measure the growth actions of area, production and yield for selected crops in Tamilnadu. In his study, maize was recorded as a positive trend in Tamilnadu. Sakthi mandal (2012) studied the spatial variation of agriculture productivity using $\mathrm{Z}$ score model and categorized the blocks as Very high, High, Medium and Low of agricultural productivity in south 24 PGS, Districts of West Bengal. Muthumurugan et al. (2012) suggested composite index analysis to study the agriculture development of Tamilnadu. He classified the districts based on the index value as highly developed, medium developed and low developed. Shymal Dutta (2012) analyzed agricultural efficiency and backwardness of agricultural production in Hugli district of west bengal, he applied agricultural efficiency index proposed by S.S Bhatia and classified the productivity regions as very high efficiency, high efficiency, moderate and low efficiency regions. Arul Kumar C and Manimanan G (2014) have applied multivariate statistical techniques for the purposes of data reduction and classification. The results falls under three categories of classes, namely high, moderate and low yield of agriculture productivity for 14 crops in north western zone of Tamilnadu. The main objective of this research paper is (i) to assess the agriculture productivity performance of Tamilnadu during the period 2007-08 to 2016-17 using composite agriculture productivity index method and (ii) to calculate three years moving average method of time series.

\section{Materials AND Methods}

\subsection{Composite Agriculture Productivity Index}

The study makes an attempt to assess the agriculture productivity performance in districts of Tamilnadu during the study period. The study entirely based on secondary data. The data has been collected from Department of Economics and Statistics, Chennai for the period of 2007-08 to 201617. In this study 15 major crops cultivated in the districts of Tamilnadu were selected carefully to assess the performance of agriculture productivity. They are Paddy, Cholam, Cumbu, Ragi, Maize, Bengal gram, Red gram, Green gram, Black gram, Horsegram, Tapioca, Ground nut, Gingely, Coconut and Sugarcane. Initially 31 districts are taken for the study and finally 28 districts are considered for the analysis, 3 districts are discarded as outliers due to non availability of data for few years. To measure the agriculture efficiency a Composite Productivity Index - the statistical technique suggested by S.S Bhatia (1967) has been applied in this study. According to Bhatia, per hectare yield expresses all the physical and human factors connected with the production of crops and the distribution of area under cultivation among various crops. Thus, a weighted average of yield productivity of all crops, would give a measure of composite agricultural productivity. The method followed to estimate Composite Agriculture Productivity Index (CAPI) is as follows,

$I_{y a}=\frac{Y_{d}}{Y_{s}} * 100$

Where $I_{y a}$ is the yield index of crop ' $a$ ', $Y_{d}$ is the hectare yield of crop 'a' in a particular district, $Y_{s}$ is the hectare yield of crop ' $a$ ' in the entire state. Then, the Composite Agricultural Productivity Index (CAPI) is estimated as follows

$C A P I=\frac{I_{y a} * C_{a}+I_{y b} * C_{b}+\ldots+I_{y n} * C_{n}}{C_{a}+C_{b}+\ldots+C_{n}}$,

Where $I_{y_{a}}, I_{y_{b}} \ldots I_{y_{n}}$ are the yield indicators of various crops and $C_{a}+C_{b}+\ldots+C_{n}$ are the percentage share of crop and under different crops. Using the above formula the productivity index was calculated for various districts in Tamilnadu.

In order to assess and classify the productivity regions in Tamilnadu the statistical method quartiles was applied to the productivity indices. Quartiles are three points that divide a range of data set into 
Assessment of Agriculture Productivity Performance in the Region of Tamilnadu Using Composite Agriculture Productivity Index

four equal parts. The first quartile is the number below which lies the 25 percent of the bottom data. The second quartile divides the range in the middle and has 50 percent of the data below it. The third quartile has 75 percent of the data below it and the top 25 percent of the data above it. In this research paper for the classification purpose, quartiles were also calculated for agriculture productivity index values to classify the productivity in districts of Tamilnadu. The algorithm for classification procedure is as follows:

Step 1: The index value which lies below in the first quartile was named as Low Productivity Districts (LPD)

Step 2: The districts which have the index value lies between first and third quartiles is marked as Moderate Productivity Districts (MPD).

Step 3: The districts index values which lies above the third quartile is named as High Productivity Regions (HPD).

\subsection{Three Years Moving Average Method of Time Series}

Moving average method to reduces the fluctuations in the trend line to a show smoother pattern. This trend line is not available if the data series contains any zero or negative numbers, the researcher use the period field to specify the number of data values to create the line. In MS-Excel creates the line by averaging the specific data values. The following steps are to be executed for the moving average for a given agriculture database.

Step 1: If the period value is 3, the first three values are averaged, that value is the second point on the line, and then the second, third and fourth values are averaged and that becomes the third point, and so on.

Step 2: A moving average trend line smoothes out fluctuations in data to show a pattern or trend more clearly. A moving average uses a specific number of data points (set by the Period option), averages them, and uses the average value as a point in the line.

Step 3: A moving average trend line is computed by using the following equation

$$
F_{t}=\frac{A_{t}+A_{t-1}+A_{t-2}+A_{t-3}+\ldots}{n}
$$

\section{RESULTS AND DISCUSSION}

In this research paper an attempt is made to assess the agriculture productivity performance of various districts in Tamilnadu over the decade. Composite Agriculture Productivity Index (CPAI) was calculated and these values are used to classify the districts as High Productivity Districts (HPD), Moderate Productivity Districts (MPD) and Low Productivity Districts (LPD). The Index values are shown in Table 1 and the classification of districts based on indices is shown in Table 2.

Table1. Composite Agricultural Productivity Indices

\begin{tabular}{|c|c|c|c|c|c|c|}
\hline $\begin{array}{c}\text { S } \\
\text {.No }\end{array}$ & Districts & $\mathbf{2 0 0 7 - 0 8}$ & $\mathbf{2 0 0 8 - 0 9}$ & $\mathbf{2 0 0 9 - 1 0}$ & $\mathbf{2 0 1 0 - 1 1}$ & $\mathbf{2 0 1 1 - 1 2}$ \\
\hline 1 & Kancheepuram & 114.03 & 128.30 & 109.61 & 122.65 & 108.99 \\
\hline 2 & Thiruvalluvar & 121.62 & 127.40 & 125.82 & 132.97 & 118.38 \\
\hline 3 & Cuddalore & 110.49 & 111.30 & 101.51 & 98.03 & 107.63 \\
\hline 4 & Villupuram & 76.17 & 115.69 & 108.05 & 100.85 & 100.45 \\
\hline 5 & Vellore & 109.04 & 105.28 & 106.63 & 87.43 & 89.08 \\
\hline 6 & Thiruvannamalai & 77.78 & 89.58 & 71.77 & 84.23 & 89.13 \\
\hline 7 & Salem & 97.48 & 103.80 & 107.88 & 111.07 & 93.60 \\
\hline 8 & Namakkal & 124.95 & 126.99 & 113.01 & 130.71 & 138.18 \\
\hline 9 & Dharmapuri & 84.80 & 77.36 & 101.65 & 117.67 & 104.80 \\
\hline 10 & Coimbatore & 85.13 & 90.82 & 97.41 & 95.29 & 104.03 \\
\hline 11 & Erode & 80.77 & 102.40 & 125.16 & 126.71 & 116.35 \\
\hline 12 & Trichy & 109.04 & 94.36 & 80.99 & 78.59 & 90.71 \\
\hline 13 & Karur & 47.39 & 61.39 & 62.82 & 57.99 & 63.09 \\
\hline 14 & Perambalur & 92.66 & 94.06 & 87.61 & 95.39 & 83.30 \\
\hline 15 & Pudukottai & 83.28 & 83.51 & 99.99 & 102.73 & 110.02 \\
\hline
\end{tabular}


Assessment of Agriculture Productivity Performance in the Region of Tamilnadu Using Composite Agriculture Productivity Index

\begin{tabular}{|l|c|c|c|c|c|c|}
\hline 16 & Thanjavur & 96.85 & 120.33 & 88.81 & 108.41 & 90.80 \\
\hline 17 & Thiruvarur & 68.33 & 86.64 & 67.26 & 57.84 & 84.26 \\
\hline 18 & Nagapattinam & 62.10 & 76.31 & 59.99 & 58.91 & 98.21 \\
\hline 19 & Madurai & 111.72 & 97.83 & 108.44 & 119.78 & 88.01 \\
\hline 20 & Theni & 150.45 & 130.91 & 147.02 & 177.16 & 131.70 \\
\hline 21 & Dindugul & 110.72 & 115.06 & 116.00 & 101.99 & 99.07 \\
\hline 22 & Ramanathapuram & 63.70 & 63.26 & 92.09 & 68.34 & 85.24 \\
\hline 23 & Virudhunagar & 115.54 & 103.13 & 108.57 & 96.91 & 132.79 \\
\hline 24 & Sivagangai & 84.33 & 77.74 & 94.05 & 86.01 & 79.20 \\
\hline 25 & Tirunelveli & 98.72 & 101.40 & 121.26 & 124.63 & 107.95 \\
\hline 26 & Thoothukudi & 102.61 & 110.66 & 130.37 & 118.40 & 112.37 \\
\hline 27 & Nilgiris & 108.65 & 116.05 & 100.42 & 103.49 & 86.69 \\
\hline 28 & Kanyakumari & 121.69 & 83.77 & 99.70 & 105.91 & 39.11 \\
\hline
\end{tabular}

Table2. Composite Agricultural Productivity Indices (Contd...)

\begin{tabular}{|c|c|c|c|c|c|c|}
\hline $\begin{array}{c}\mathrm{S} \\
. \mathrm{No} \\
\end{array}$ & Districts & $2012-13$ & 2013-14 & 2014-15 & $2015-16$ & $2016-17$ \\
\hline 1 & Kancheepuram & 140.52 & 142.40 & 144.04 & 143.22 & 115.15 \\
\hline 2 & Thiruvalluvar & 146.06 & 144.14 & 121.47 & 113.93 & 98.38 \\
\hline 3 & Cuddalore & 93.31 & 97.18 & 111.13 & 103.25 & 88.26 \\
\hline 4 & Villupuram & 106.75 & 97.43 & 96.63 & 108.74 & 94.70 \\
\hline 5 & Vellore & 99.13 & 80.85 & 97.00 & 78.94 & 92.70 \\
\hline 6 & Thiruvannamalai & 118.05 & 92.00 & 86.89 & 88.96 & 96.57 \\
\hline 7 & Salem & 96.21 & 90.96 & 100.97 & 123.13 & 105.68 \\
\hline 8 & Namakkal & 109.58 & 107.76 & 108.88 & 103.59 & 97.45 \\
\hline 9 & Dharmapuri & 123.44 & 99.31 & 95.73 & 100.91 & 105.51 \\
\hline 10 & Coimbatore & 100.86 & 57.40 & 111.57 & 96.47 & 96.55 \\
\hline 11 & Erode & 121.11 & 122.46 & 116.55 & 120.99 & 104.04 \\
\hline 12 & Trichy & 88.87 & 80.02 & 103.41 & 95.84 & 85.09 \\
\hline 13 & Karur & 100.12 & 68.95 & 71.98 & 72.75 & 102.63 \\
\hline 14 & Perambalur & 59.59 & 44.04 & 69.86 & 78.30 & 97.46 \\
\hline 15 & Pudukottai & 82.78 & 79.14 & 86.56 & 88.51 & 99.40 \\
\hline 16 & Thanjavur & 75.60 & 97.06 & 103.93 & 100.01 & 119.23 \\
\hline 17 & Thiruvarur & 71.69 & 51.30 & 87.63 & 66.36 & 84.76 \\
\hline 18 & Nagapattinam & 31.19 & 36.75 & 81.28 & 91.52 & 70.21 \\
\hline 19 & Madurai & 88.97 & 96.94 & 77.29 & 117.86 & 111.27 \\
\hline 20 & Theni & 151.07 & 128.91 & 184.52 & 180.92 & 140.37 \\
\hline 21 & Dindugul & 109.20 & 103.94 & 115.58 & 121.59 & 113.59 \\
\hline 22 & Ramanathapuram & 55.20 & 70.87 & 66.68 & 74.98 & 82.25 \\
\hline 23 & Virudhunagar & 122.37 & 104.26 & 81.51 & 91.81 & 103.31 \\
\hline 24 & Sivagangai & 65.81 & 74.40 & 70.97 & 89.09 & 96.61 \\
\hline 25 & Tirunelveli & 131.54 & 101.57 & 126.50 & 94.36 & 116.75 \\
\hline 26 & Thoothukudi & 162.64 & 128.86 & 103.51 & 81.21 & 127.62 \\
\hline 27 & Nilgiris & 103.77 & 93.83 & 89.10 & 92.41 & 86.15 \\
\hline 28 & Kanyakumari & 61.28 & 79.07 & 104.47 & 122.16 & 72.53 \\
\hline
\end{tabular}

Table3. Classification of Districts

\begin{tabular}{|c|c|c|c|c|c|c|}
\hline \multirow[b]{2}{*}{ Year } & \multicolumn{2}{|c|}{ Low Productivity Districts } & \multicolumn{2}{|c|}{ Moderate Productivity Districts } & \multicolumn{2}{|c|}{ High Productivity Districts } \\
\hline & Index Range & No. of Districts & Index Range & No. of Districts & Index Range & $\begin{array}{c}\text { No. of } \\
\text { Districts }\end{array}$ \\
\hline $2007-2008$ & Below 81.39 & $\begin{array}{c}{[4],[6],[11],[13],} \\
{[17],[18],[22]}\end{array}$ & $81.39-111.47$ & $\begin{array}{c}3],[5],[7],[9], \\
{[10],[12],[14],} \\
{[15] .[16],[21],} \\
{[24],[25],[26],} \\
{[27]}\end{array}$ & Above 114.47 & $\begin{array}{c}{[1],[2],} \\
{[8],[19],} \\
{[20],[23],} \\
{[28]}\end{array}$ \\
\hline $2008-2009$ & Below 84.48 & $\begin{array}{c}{[9],[13],[15],} \\
{[18],[22],[24],} \\
{[28]}\end{array}$ & $84.48-115.5$ & $\begin{array}{c}3],[5],[6],[7], \\
{[10],[11],[12],} \\
{[14],[17],[19],} \\
{[21],[23],[25],} \\
{[26]}\end{array}$ & Above 115.5 & $\begin{array}{c}\text { [1], [2], } \\
{[4],[8],} \\
{[16],[20],} \\
{[27]}\end{array}$ \\
\hline
\end{tabular}


Assessment of Agriculture Productivity Performance in the Region of Tamilnadu Using Composite Agriculture Productivity Index

\begin{tabular}{|c|c|c|c|c|c|c|}
\hline 2009-2010 & Below 89.63 & $\begin{array}{c}{[6],[12],[13],} \\
{[14],[16],[17],} \\
{[18]}\end{array}$ & $89.63-112.16$ & $\begin{array}{c}{[1],[3],[4],[5],} \\
{[7],[9],[10],[15],} \\
{[19],[22],[23],} \\
{[24],[27],[28]}\end{array}$ & Above 112.16 & $\begin{array}{c}{[2],[8],} \\
{[11],[20],} \\
{[21],[25],} \\
{[26]}\end{array}$ \\
\hline 2010-2011 & Below 86.36 & $\begin{array}{c}\text { [6], [12], [13], } \\
{[17],[18],[22],} \\
{[24]}\end{array}$ & $86.36-119.43$ & $\begin{array}{c}3],[4],[5],[7], \\
{[9],[10],[14],[15],} \\
{[16],[21],[23],} \\
{[26],[27],[28]}\end{array}$ & Above 119.43 & $\begin{array}{c}\text { [1], [2], } \\
{[8],[11],} \\
{[19],[20],} \\
{[25]}\end{array}$ \\
\hline 2011-2012 & Below 87.01 & $\begin{array}{c}{[13],[14],[17],} \\
{[22],[24],[27],} \\
{[28]}\end{array}$ & $87.01-109.76$ & $\begin{array}{c}{[1],[3],[4],[5],} \\
{[6],[7],[9],[10],} \\
{[12],[16],[18],} \\
{[19],[21],[25]}\end{array}$ & Above 109.76 & $\begin{array}{c}2],[8], \\
{[11],[15],} \\
{[20],[23],} \\
{[26]}\end{array}$ \\
\hline 2012-2013 & Below 77.39 & $\begin{array}{c}{[14],[16],[17],} \\
{[18],[22],[24],} \\
{[28]}\end{array}$ & $77.9-122.05$ & $\begin{array}{c}3],[4],[5],[6], \\
{[7],[8],[10],[11],} \\
{[12],[13],[15],} \\
{[19],[21],[27]}\end{array}$ & Above 122.05 & $\begin{array}{c}\text { [1], [2], } \\
{[9],[20],} \\
{[23],[25],} \\
{[26]}\end{array}$ \\
\hline 2013-2014 & Below 75.57 & $\begin{array}{c}{[10],[13],[14],} \\
{[16],[18],[21],} \\
{[24]}\end{array}$ & $75.57-104.18$ & $\begin{array}{c}3],[4],[5],[6], \\
{[7],[9],[12],[15],} \\
{[17],[19],[22],} \\
{[25],[27],[28]}\end{array}$ & Above 104.18 & $\begin{array}{c}\text { [1], [2], } \\
{[8],[11],} \\
{[20],[23],} \\
{[26]}\end{array}$ \\
\hline 2014-2015 & Below 82.77 & $\begin{array}{c}\text { [13], [14], [18], } \\
{[19],[24]}\end{array}$ & $82.77-111.46$ & $\begin{array}{c}\text { [3], [4], [5], [6], } \\
{[7],[8],[9],[12],} \\
{[15],[16],[17],} \\
{[22],[23],[26],} \\
{[27],[28]}\end{array}$ & Above 111.46 & $\begin{array}{c}{[1],[2],} \\
{[10],[11],} \\
{[20],[21],} \\
{[25]}\end{array}$ \\
\hline 2015-2016 & Below 88.62 & $\begin{array}{l}{[5],[13],[14],} \\
{[17],[22],[26]}\end{array}$ & $88.62-116.88$ & $\begin{array}{c}2],[3],[4],[6], \\
{[8],[9],[10],[12],} \\
{[15],[16],[18],} \\
{[23],[24],[25],} \\
{[27]}\end{array}$ & Above 116.88 & $\begin{array}{c}{[1],[7],} \\
{[11],[19],} \\
{[20],[21],} \\
{[28]}\end{array}$ \\
\hline 2016-2017 & Below 89.33 & $\begin{array}{c}\text { [3],[12], [17], } \\
{[18],[22],[28]}\end{array}$ & $89.36-109.8$ & $\begin{array}{c}{[2],[4],[5],[6],[7],} \\
{[8],[9],[10],[11],} \\
{[13],[14],[15],} \\
{[21],[23],[24],} \\
{[27]}\end{array}$ & Above 109.8 & $\begin{array}{l}{[1],[16],} \\
{[19],[20],} \\
{[25],[26]}\end{array}$ \\
\hline
\end{tabular}

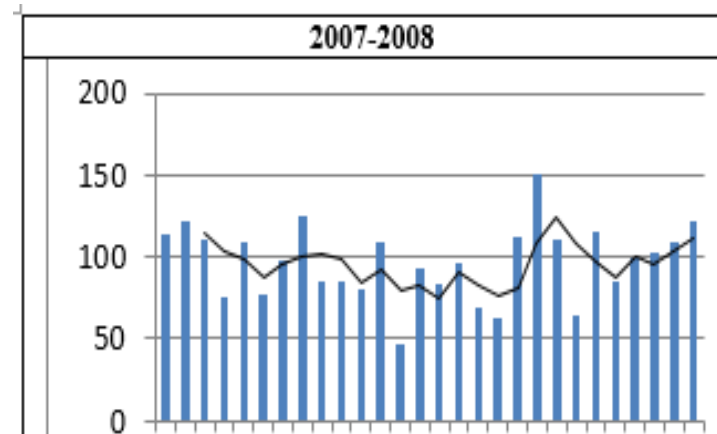

1335799111315171921232527

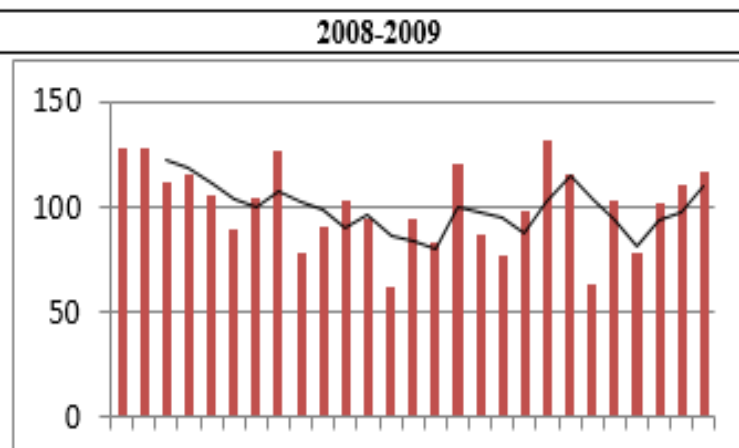

$\begin{array}{llllllllllllll}1 & 3 & 5 & 7 & 9 & 11 & 13 & 15 & 19 & 21 & 23 & 25 & 27\end{array}$

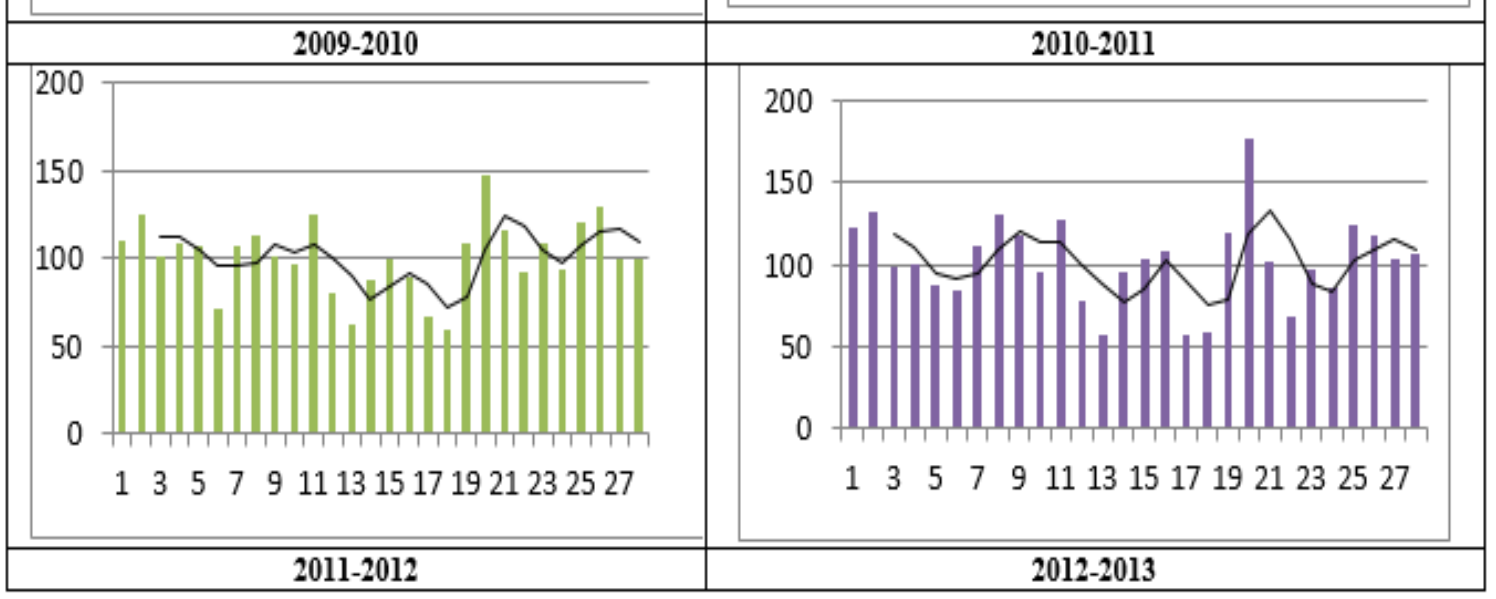

Fig1. Composite Index and three years moving average trend line for ten years 
From Table 2 and Fig 1 it is observed that the overall agriculture productivity performance of Tamilnadu is not encouraging and shows that the fluctuations of three years moving average trend line for the ten years period. It was noticed that $50 \%$ of the districts performance is Moderate during the study period. Only $25 \%$ of the districts observed with high productivity performance and $25 \%$ of districts marked with low productivity performance. Among the districts of Tamilnadu, Theni [20] district observed the bar chart and trend line consistent high performance in all ten year period and Nagapattinam [18] showed the bar chart and trend line in low performance in terms of productivity during the entire study period. Kancipuram[1] and Thriuvalluvar [2] districts show high performance in eight years and moderate performance in two years. Low performance was recorded for seven years in Ramanathapuram [22] district and eight years in Karur [13]. Cuddalore, Vellore and Salem marked with moderate performance during the study period. The variations in the agriculture productivity are due to changing rainfall pattern in Tamilnadu over the years, ground water depletion, lack of flows in perennial rivers, scarcity of labours, large chunk of rainfed area, overdue monsoons, uncertainty dates of opening and closing of Mettur dam water for irrigation and lack of drainage facility in the delta districts.

\section{CONCLuSion}

In this research paper, the agriculture productivity performance and moving average method of various districts in Tamilnadu was studied during 2007-08 to 2016-17 using Composite Agriculture Productivity Index. The districts were classified as High Productivity, Moderate Productivity and Low Productivity districts based on the productivity of major crops. It is found that the scenario of agriculture productivity in Tamilnadu during the study period was not encouraging. It was noticed that nearly $75 \%$ districts observed with low and moderate productivity. There are no significant changes in the productivity during the study period. To increase the agriculture productivity in Tamilnadu the emphasis should be laid on reform measures, technological changes, infrastructure development, application of new agricultural technology brought with high yielding varieties which may suit to the agro climatic zone will be of great help.

\section{REFERENCES}

[1] Arulkumar C and Manimannan G (2014), Agriculture Productivity Performance of North- Western Zone in Tamilnadu Using Data Mining Techniques, International Journal of Statistika and Mathematika, Volume 10, Issue 1, pp. 1-7.

[2] Kalaivani M and A. Saravanadurai (2010), Growth Actions of Selected Cereal crops in Tamil Nadu state, International Journal of Applied Biology and Pharmaceutical Technology, Vol I; issue 3, pp 778-785.

[3] Kendal M.G (1939) The Geographical Distribution of Crop Production in England, Journal of Royal Statistical Society, Volume 102 pp. 21-26.

[4] Lal Mervin Dharmasiri (2010), Measuring Agricultural Productivity using the Average Productivity Index, Srilanka Journal of Adanced Social Studies vol.1 - No.2.

[5] Muthumurugan et al. (2012), Composite Index Analysis of Inter-Regional Variations in Agricultural Development of Tamil Nadu, International Journal of Social Sciences and Inter Disciplinary Research Vol.1 No.4 pp 58-62.

[6] Sakthi Mandal and Arijit Dhara (2012), Measurement of Agricultural productivity and levels of development in south 24 pargans district, West Bengal, International Journal of Agricultural Science and Research Vol.2 Issue 4 pp 91-98.

[7] Shafi M (1960), Measurement of Agricultural efficiency in Uttar Pradesh, Economic Geography, Volune 36, No. 34 pp.296-305.

[8] Shafi M (1984), Agricultural productivity and Regional imbalances, New Delhi, Concept Publishing Company.

[9] Shyamal Dutta (2012) Assessment of Agricultural Efficiency and Productivity: A study of Hugli district, West Bengal. International Journal of Current Research Vol 4, Issue 11, pp. 190-195.

[10] Season and Crop Report, Department of Economics and Statistics, Chennai. (Various issues).

[11] Singh J and Dhillion, S.S, (2000), Agricultural Geography ( $2^{\text {nd }}$ edition) New Delhi, Tata McGraw Hill.

[12] Stamp L.D (1958), The measurement of Land Resources, the Geographical Review Vol.48 No.1 pp.110116. 
Assessment of Agriculture Productivity Performance in the Region of Tamilnadu Using Composite Agriculture Productivity Index

[13] State of Indian Agriculture 2012-2013, Government of India, Ministry of Agriculture, Department of Agriculture and Cooperation, Directorate of Economics and Statistics, New Delhi.

[14] Statistical Hand Book of Tamilnadu 2016-201, Department of Economics and Statistics, Chennai.

Citation: Manimannan. G,et.al., (2019). Assessment of Agriculture Productivity Performance in the Region of Tamilnadu Using Composite Agriculture Productivity Index. International Journal of Scientific and Innovative Mathematical Research (IJSIMR), 7(4), pp.1-7. http://dx.doi.org/10.20431/2347-3142.0704001

Copyright: (C) 2019 Authors, This is an open-access article distributed under the terms of the Creative Commons Attribution License, which permits unrestricted use, distribution, and reproduction in any medium, provided the original author and source are credited. 